\title{
Relationship Between Industrial Production and Pawnshop Market of the Ural Macroregion
}

\author{
Natalia Novikova*, and Mariia Rigel \\ Ural State University of Economics, 620144 Ekaterinburg, Russia
}

\begin{abstract}
The article focuses on the need to study the processes of a new high-tech industrialization (neo-industrialization) at the macroregion level. The object of the study is the economic region of the Russian Federation (the macroregion) as a relatively integral spatially localized and complexly structured socio-economic entity, which includes four Ural regions Kurgan region, Orenburg region, Sverdlovsk region and Chelyabinsk region, Perm krai and two republics - Republic of Bashkortostan and Republic of Udmurtia, which corresponds to the borders of the Ural economic region according to the all-Russian classifier of economic regions. The purpose of this study is to prove the relationship between the level of industrial production and the level of the pawnshop market development in the Ural macroregion. The territory of the Ural macroregion is analyzed from the perspective of the relationship between the level of industrial production and the level of the pawnshop market development. The Authors proved the existence of a direct relationship between the level of industrial production and the level of pawnshops territorial concentration, and also identified the territories that are leaders in the pawnshops concentration. The Authors put forward a scientific hypothesis about the most effective model of pawnshop activity. The conclusion is made about mutually beneficial cooperation between precious metal processing enterprises and pawnshops, which contributes to the development of both the pawnshop sector and this type of industrial activity.
\end{abstract}

\section{Introduction}

Searching for a new model of economic development based on a new quality of economic growth that meets the challenges of the fourth industrial revolution and the accelerated formation of the fifth and sixth technological orders, scientific discussions are increasingly focused on the economic paradigm of a new industrialization (neoindustrialization). The main idea of the new industrialization is the industrial production development based on advanced modern technologies [1, 2, 3, 4, 5, 6, 7, 8].

According to the Authors, the study of new industrialization processes should be carried out at the level of regions (macroregions), due to the fact that a space with its specific conditions and factors accelerates or slows down its dynamics $[9,10,11,12]$. Therefore,

* Corresponding author: novikova@usue.ru 
the regional potential determines the initial conditions of the new industrialization in the spatial aspect.

Thus, the territorial boundaries of the study include the Kurgan, Orenburg, Sverdlovsk and Chelyabinsk regions, the Perm krai, as well as the Republics of Bashkortostan and Udmurtia, which corresponds to the borders of the Ural economic region according to the all-Russian classifier of economic regions (OK 024-95) (hereinafter the Ural macroregion).

It is obvious that each territory of the Ural macroregion has its own unique features of both industry and services development. The study revealed the relationship between the level of industrial development in a particular territory and the level of development of such a specific service sector as pawnshops.

Pawnshops are microfinance institutions that provide loans secured by property, as well as the storage of goods.

In a modern scientific research, the problems, patterns, factors, and conditions of the pawnshop market development and functioning are poorly represented. At the same time, the Authors consider a pawnshop market to be an integral part of the national, regional and local markets of services $[13,14,15]$ developing in many ways according to its laws, and having its specific features.

\section{Methods and Materials}

Pawnshops have a right to accept as collateral any movable property belonging to the borrower, with the exception of goods withdrawn from circulation, as well as goods for which the turnover of the Russian Federation legislation has appropriate restrictions. Thus, almost any liquid property can be accepted as collateral: vehicles, jewelry, household appliances and electronics, fur products, watches, antiques, jewelry of famous brands, etc. However, after analyzing the pawnshop market of the Ural macroregion, we can conclude that the vast majority of pawnshops accepts precious metal products as collateral $(95 \%$ of the market).

Given the specifics of pawnshops, this type of collateral does not require a large storage area, and the evaluation of goods is carried out using special chemical reagents, which reduces the likelihood of accepting counterfeit products as collateral. However, the main reason for choosing this type of collateral is the presence of precious metals refineries (Yekaterinburg non-ferrous metals processing plant, Uralelectromed JSC, Kyshtym copper electrolytic plant) and other plants for processing precious metals on the territory of the Ural macroregion.

Eleven plants only have a right to refine precious metals in Russia, three of which are located on the territory of the Ural macroregion (two in the Sverdlovsk region, one in the Chelyabinsk region), which makes it unique.

Non-ferrous metal working plants implement the latest technologies as well as the research and development results that can improve their products quality and reduce production costs (techniques for deeper purification of silver electrolyte, methods of electron microscopy and microanalysis, methods of x-ray spectral microanalysis etc.). Improving the precious metals refining technology allows to involve in the processing a variety of raw materials, including poor in gold and silver content. There is no doubt that these activities have a significant impact on the level of the territories' industrial development.

The Russian lawmaking has provided for pawnshops a right to sell unclaimed property. Thus, the Ural macroregion pawnshops have the opportunity to sell non-purchased products made of precious metals to refining.

To conduct our own research, we used rating methods and regional comparative analysis to identify factors of territorial differentiation. 


\section{Results and Discussions}

Within a framework of a long-term scientific research N.V. Novikova has developed a method for assessing the industrial potential of a new industrialization in the context of the Ural macroregion territories [16]. Based on this methodology, we present an analysis of the level of pawnshop activity concentration subject to the level of industrial production development.

To analyze the level of pawnshops distribution and concentration by territory, as well as the relationship with the indicator of industrial potential, we use the data presented in a table below (table 1).

Table 1. Initial data for analyzing the relationship between the industrial production level and the level of pawnshops distribution in the Ural macroregion

\begin{tabular}{|c|c|c|c|c|}
\hline $\begin{array}{l}\text { Territories of the Ural } \\
\text { macroregion }\end{array}$ & $\begin{array}{c}\text { Aggregate } \\
\text { indicator of the } \\
\text { region's } \\
\text { industrial } \\
\text { potential }\end{array}$ & $\begin{array}{c}\text { Number of } \\
\text { registered } \\
\text { pawnshops as } \\
\text { of 01.01.2020, } \\
\text { units }\end{array}$ & $\begin{array}{c}\text { Population } \\
\text { as of } \\
\mathbf{0 1 . 0 1 . 2 0 2 0} \\
\text { thousand } \\
\text { people }\end{array}$ & $\begin{array}{c}\text { Number of } \\
\text { pawnshops } \\
\text { per 100 } \\
\text { thousand } \\
\text { people, units }\end{array}$ \\
\hline Sverdlovsk region & 1,064 & 106 & 4311 & 2 \\
\hline Chelyabinsk region & 1,039 & 88 & 3466 & 3 \\
\hline Republic of Bashkortostan & 0,993 & 65 & 4038 & 2 \\
\hline Republic of Udmurtia & 0,983 & 26 & 1501 & 2 \\
\hline Perm krai & 0,978 & 87 & 2599 & 3 \\
\hline Orenburg region & 0,976 & 55 & 1957 & 3 \\
\hline Kurgan region & 0,837 & 9 & 827 & 1 \\
\hline
\end{tabular}

Table 2. The Ural macroregion territories` ranks based on the research results

\begin{tabular}{|c|c|c|c|}
\hline $\begin{array}{c}\text { Territories of the Ural } \\
\text { macroregion }\end{array}$ & $\begin{array}{c}\text { Territory`s rank by } \\
\text { the level of industrial } \\
\text { development }\end{array}$ & $\begin{array}{c}\text { Territory`s rank by } \\
\text { the number of } \\
\text { registered pawnshops }\end{array}$ & $\begin{array}{c}\text { Territory`s rank by } \\
\text { the level of } \\
\text { pawnshops } \\
\text { concentration per 100 } \\
\text { thousand people }\end{array}$ \\
\hline Sverdlovsk region & 1 & 1 & 2 \\
\hline Chelyabinsk region & 2 & 2 & 1 \\
\hline $\begin{array}{c}\text { Republic of } \\
\text { Bashkortostan }\end{array}$ & 3 & 4 & 2 \\
\hline Republic of Udmurtia & 4 & 6 & 1 \\
\hline Perm Krai & 5 & 3 & 1 \\
\hline $\begin{array}{c}\text { Orenburg } \\
\text { region }\end{array}$ & 6 & 5 & 3 \\
\hline $\begin{array}{c}\text { Kurgan } \\
\text { region }\end{array}$ & 7 & 7 & 2 \\
\hline
\end{tabular}

The analysis allows us to conclude that there is a relationship between the level of industrial production development and the number of pawnshops in the given territory. The leadership of the Sverdlovsk and Chelyabinsk regions confirms the hypothesis of the pawnshops activity concentration in close proximity to precious metals refineries. In the ranking by the level of pawnshops concentration in the region, the leading positions are occupied by the Chelyabinsk region, as well as the Perm krai and the Orenburg region. At the same time, according to the level of industrial development, the Perm region and the Orenburg region are on the 5th and 6th places, respectively. Thus, it can be assumed that in these territories, the pawnshop market development is additionally influenced by other factors.

The Authors give consideration to the indicator of an overdue debt on loans provided by pawnshops. If the loan is not repaid by the borrower within the term established by the agreement, it is considered overdue, and the property after 30 calendar days is unclaimed. 
Thus, the analysis of the overdue debt allows us to draw a conclusion about the array of unclaimed property in monetary terms. In general, in Russia, the specified value at the end of the first half of the year 2020 reaches 21 billion rubles. In the Ural macroregion this indicator comes up to 3 billion rubles.

Table 3. Data for analyzing the overdue debt on loans provided by pawnshops as of the end of the first half of the year 2020

\begin{tabular}{|c|c|c|c|c|c|}
\hline Territory & $\begin{array}{c}\text { Overdue } \\
\text { debt on } \\
\text { loans, } \\
\text { thousand } \\
\text { rubles }\end{array}$ & $\begin{array}{c}\text { Indicator of } \\
\text { overdue debt, } \\
\text { thousand } \\
\text { rubles }\end{array}$ & $\begin{array}{c}\text { Number of } \\
\text { current loan } \\
\text { agreements, } \\
\text { units }\end{array}$ & $\begin{array}{c}\text { Number of } \\
\text { borrowers } \\
\text { under current } \\
\text { loan } \\
\text { agreements, } \\
\text { people }\end{array}$ & $\begin{array}{c}\text { Modal per } \\
\text { capita } \\
\text { income, } \\
\text { rubles per } \\
\text { month* }\end{array}$ \\
\hline Chelyabinsk region & 2832967 & 1643099 & 352570 & 221055 & 13935,8 \\
\hline Sverdlovsk region & 1539635 & 857529 & 158365 & 88081 & 16784,5 \\
\hline $\begin{array}{c}\text { Republic of } \\
\text { Bashkortostan }\end{array}$ & 544167 & 277087 & 61128 & 36461 & 13000,7 \\
\hline Orenburg region & 317008 & 85080 & 64598 & 34248 & 12044,3 \\
\hline Republic of Udmurtia & 120982 & 64340 & 27878 & 13035 & 13522,1 \\
\hline Perm krai & 126631 & 63394 & 24159 & 14325 & 13500,7 \\
\hline Kurgan region & 31727 & 13650 & 5693 & 3729 & 11499,6 \\
\hline Russia in total & 37617 & 21415778 & 3730363 & 2179818 & 14750,1 \\
\hline
\end{tabular}

* Data are given as of 31.12.2019.

Table 4. Overdue debt on loans granted as of the end of the first half of the year 2020

\begin{tabular}{|c|c|c|c|c|c|}
\hline Territory & $\begin{array}{l}\text { Share of } \\
\text { overdue } \\
\text { debt from } \\
\text { total debt, } \\
\text { \% }\end{array}$ & $\begin{array}{l}\text { Share of } \\
\text { overdue debt } \\
\text { in Russia, \% }\end{array}$ & $\begin{array}{c}\text { Share of overdue } \\
\text { debt in the Ural } \\
\text { macroregion, \% }\end{array}$ & $\begin{array}{c}\text { Average } \\
\text { amount of } \\
\text { overdue debt } \\
\text { per 1 } \\
\text { orrower, } \\
\text { thousand } \\
\text { rubles }\end{array}$ & $\begin{array}{c}\text { Average } \\
\text { amount of } \\
\text { overdue debt } \\
\text { per 1 loan } \\
\text { agreement, } \\
\text { thousand } \\
\text { rubles }\end{array}$ \\
\hline $\begin{array}{c}\text { Chelyabinsk } \\
\text { region }\end{array}$ & 58,00 & 7,67 & 54,69 & 7,43 & 4,66 \\
\hline $\begin{array}{c}\text { Sverdlovsk } \\
\text { region }\end{array}$ & 55,70 & 4,00 & 28,54 & 9,74 & 5,41 \\
\hline $\begin{array}{c}\text { Republic of } \\
\text { Bashkortostan }\end{array}$ & 50,92 & 1,29 & 9,22 & 7,60 & 4,53 \\
\hline $\begin{array}{c}\text { Orenburg } \\
\text { region }\end{array}$ & 26,84 & 0,40 & 2,83 & 2,48 & 1,32 \\
\hline $\begin{array}{c}\text { Republic of } \\
\text { Udmurtia }\end{array}$ & 53,18 & 0,30 & 2,14 & 4,94 & 2,31 \\
\hline Perm krai & 50,06 & 0,30 & 2,11 & 4,43 & 2,62 \\
\hline Kurgan region & 43,02 & 0,06 & 0,45 & 3,66 & 2,40 \\
\hline Russia in total & 56,93 & 100,00 & - & 9,82 & 5,74 \\
\hline
\end{tabular}

The results shown in the Table 4 allow us to draw the following conclusions:

1. Chelyabinsk and Sverdlovsk regions remain leaders among other territories of the Ural macroregion in terms of the overdue debt. This indicator is compliant with the all-Russian trend.

2. The maximum ratio of the overdue debt amount per 1 borrower, as well as per 1 loan agreement, is noted in the Sverdlovsk region.

3. The highest level of the income per capita is observed in the Sverdlovsk and Chelyabinsk regions. Thus, the nature of the relationship between the level of the income per capita and the level of the overdue debt requires additional research.

After analyzing the structure of the pawnshop market in the leading territories, we can distinguish the following model of their activity: a pawnshop forming part of a federal 
chain (offices outside the territory of a legal entity registration), which is a part of a group of companies (companies providing advertising services, security, rental of premises, as well as enterprises processing precious metal scrap).

Thus, pawnshops of the Sverdlovsk and Chelyabinsk regions have access to the sale of the unclaimed property made of precious metals through non-ferrous metal working plants, enterprises processing precious metals, which simplifies the implementation procedure and ensures rapid turnover of assets.

The volume of non-ferrous metal working plants activity is not comparable to the volume of the pawnshop sector activity for the sale of precious metal products. Thus, this cooperation is more profitable and necessary for pawnshops. A group of companies including a precious metals refinery and a pawnshop contributes to the development of both the pawnshop industry and the precious metals processing industry on the given territory.

\section{Conclusions}

1. The new industrialization is associated with the development of industrial production. The authors are convinced that the study of neo-industrialization processes should be carried out at the level of macroregions, since the regional potential determines the initial conditions of a new industrialization in the spatial aspect.

2. The results of the study indicate a direct relationship between the industrial production development and the pawnshop market development.

3. The presence of three precious metals refineries on the territory of the Ural macroregion makes it unique among other macroregions.

4. The level of the territory's industry development, as well as the level of the territorial pawnshops distribution, is the highest in the Sverdlovsk and Chelyabinsk regions. This is due both to the model of pawnshops ' activities in these territories, and to the presence of the precious metal refining plants and enterprises for processing precious metal scrap in these regions.

\section{References}

1. J. W. Forreste, Industrial Dynamics, 336 (1961)

2. K. Perez-Perez, Futures, 15, 357 (1983)

3. M. Jenike, K. Jakob // Internationale Politik, 5, 38 (2008)

4. K. Schwab, The fourth industrial revolution, 208 (2017)

5. K. Schwab, N. Davis, Technology of the fourth industrial revolution, 320 (2018)

6. S. D. Bodrunov, The future. New industrial society: reboot , 2, 328 (2016)

7. S. D. Bodrunov, RS Grinberg, D. E. Sorokin, Economic revival of Russia, 1(35), 19 (2013)

8. S. D. Bodrunov, Economic revival of Russia, 2, 5 (2014)

9. O.A. Romanova, Economy of the region, 2, 70 (2012)

10. E.G. Animitsa, J.P. Silin, Economy of the region, 3, 71 (2013)

11. N. V. Novikova, New industrialization: a regional paradigm, 264 (2018)

12. Ya. P. Silin, Ye. G. Animitsa, N. V. Novikova, Ural macro-region: large cycles of industrialization, 371 (2019)

13. E.B. Dvoryadkina, News of the Ural State University of Economics, 1(51), 43 (2014) 
14. E.B. Dvoryadkina, N.V. Novikova, D.Yu. Verevkin, Local consumer market: network aspects of development, 137 (2010)

15. A.S. Novoselov, The theory of regional markets, 448 (2002)

16. N.V. Novikova, Regional economy: challenges, priorities, strategic guidelines, 152 (2017) 